\title{
Esensi Pragmatis Karya Konsepsual Dalam Proyek Desain Interior
}

\author{
Anak Agung Gede Ardana ${ }^{1}$, Ni Luh Kadek Resi Kerdiati ${ }^{2}$ \\ 1,2. Program Studi Desain Interior Fakultas Seni Rupa dan Desain \\ Institut Seni Indonesia Denpasar \\ arland_agung@yahoo.com,resikerdiati@isi-dps.ac.id
}

Tulisan ini dibuat untuk menjelaskan bentuk karya desain interior yang berkaitan dalam pelaksanaan proyek di lapangan. Desain interior merupakan karya yang banyak dikembangkan dewasa ini dalam prosesnya diawali dengan penentuan sebuah konsep desain. Karya Desain Konsepsual merupakan produk awal dalam sebuah proses desain, dibuat dengan tujuan agar pemesan dapat dengan mudah memahami bentuk desain sesuai dengan konsep yang diinginkan. Karya ini merupakan aplikasi dari sebuah konsep yang diwujudkan dalam bentuk gambar desain yang mudah dipahami. Karya Desain Konsepsual dapat berbentuk karya dwimatra maupun trimatra seperti; gambar denah, tampak/potongan, perspektif, sket bebas, maket, animasi, moke up dan sebagainya. Penekanan karya adalah mudah dipahami dan diimaginasikan dalam bentuk kenyataan sesuai dengan konsep yang ditentukan. Bentuk, dimensi, warna dan bayangan menjadi perhatian, agar secara tiga dimensi bentuk desain dapat dipahami dengan mudah. Karya Desain Konsepsual harus bisa menampilkan secara visual karakter konsep dalam desain, sehingga orang yang melihat karya tersebut dapat merasakan suasana sesuai konsep yang ada di dalamnya. Pada akhirnya seluruh karya ini dipergunakan sebagai materi presentasi untuk menjelaskan seluruh desain yang berhubungan dengan konsep terkait penyelesaian proyek nantinya. Hasil masukan dari presentasi menjadi bagian dari karya pengembangan desain dan detail yang biasanya disebut sebagai dokumen gambar kerja. Gambar kerja merupakan kelanjutan dari sebuah proses desain interior untuk pedoman bagi kontraktor dalam mewujudkan desain pada sebuah proyek.

Kata kunci: desain konsepsual, bentuk karya, proyek.

This paper is explain of drawings product of design relating to role of project construction on site. Interior design is one of the main creation nowadays begins with a concept. Conceptual Design drawing is represented beginning drawing be made in long process designing. The drawing made with a purpose client to easily understand to drawing's recording concept desired. Can be interpreted, the drawing is represented application from a concept to easily be understand. Which includes creation of conceptual design can be realized by twodimensional or tridimensional sunch as plan drawing, section \& elevation, perspective, free sketches, moke up, animation, etcetera. Emphasized creation is easily to understand and imagine in the form of reality according to concept specified. The form, dimension, coloring, shadow will attention in three dimension perceivable easily. Work of conceptual should be able to display visually concept character on the design, so that people who see the work can feel the atmosphere according to the concept. Finally all this work will be used as items of presentation to explain all of design related to the concept. Result of input presentation become part of Development and Construction Document will be used for contractor guidance to design realizing on project.

Keywords: conceptual design, design work, project.

Proses review: 1 - 15 September 2021, Dinyatakan lolos 17 September 2021 


\section{PENDAHULUAN}

Kebutuhan akan rasa nyaman dan aman dalam menjalani kehidupan masyarakat khususnya dalam beraktifitas di dalam ruang bangunan banyak diminati dewasa ini. Hal ini dapat dilihat dengan banyaknya berkembang karya-karya desain interior yang dirancang sesuai dengan kebutuhan masyarakat. Perkembangan tersebut dapat dilihat dengan munculnya berbagai bentuk desain interior pada bangunan pribadi seperti perumahan maupun bangunan publik seperti pertokoan, perkantoran dan sebagainya. Sejalan dengan pendapat Rucitra (2020) yang menyebutkan bahwa, desain adalah sebuah proses untuk mempermudah kehidupan manusia diberbagai aspek secara berkelanjutan. Lingkup pekerjaan desain interior merupakan sebuah rangkaian proses pada perencanaan fasilitas ruang yang disesuaikan dengan kebutuhan penggunanya baik secara fisik dan psikologis. Desain Interior merupakan produk yang dibuat sesuai dengan kebutuhan aktifitas pemakainya dan juga tidak lepas dari penggunaan unsur seni rupa, faktor keindahan ini menjadi bagian dari kesatuan dalam setiap bentuk yang dihasilkan desain interior, sehingga disamping dapat memberikan rasa aman dan nyaman juga memberikan daya tarik bagi orang yang melihatnya. Disebutkan keunggulan karya seni yang dihasilkan oleh seseorang sangat tergantung pada spirit yang melandasi pemikiran kreatifnya. Hal ini tidak sekedar berkaitan dengan faktor estetikanya semata, karena semua karya seni memang dibuat untuk kepentingan dan kegunaan manusia (Norman, 2013).

Perlu dijelaskan mengenai bentuk dan fungsi karya desain interior dalam tulisan ini, sehingga dapat diketahui tahapan pekerjaan desain interior secara menyeluruh. "Desain Konsepsual" adalah pekerjaan pertama yang berfungsi untuk menggambarkan suasana ruang yang diwujudkan berdasarkan konsep yang digunakan, dan dilanjutkan dengan "Desain Pengembangan" berfungsi untuk menentukan bentuk, dimensi maupun bahan setiap unsur desain dan dilanjutkan pada pengerjaan "Desain Detil" yang menguraikan seluruh bentuk desain secara detil. Dengan demikian Desain Konsepsual menjadi bagian penting dalam menentukan kelanjutan desain kedepannya karena desain tersebut menjadi pedoman pekerjaan selanjutnya. Wikipedia dalam terjemahan bebasnya menyebutkan, desain konseptual adalah fase awal dari proses desain, di mana garis besar fungsi dan bentuk sesuatu diartikulasikan. Ini mencakup desain interaksi, pengalaman, proses, dan strategi. Ini melibatkan pemahaman tentang kebutuhan masyarakat dan bagaimana memenuhi mereka dengan produk, layanan, dan proses. Artefak umum dari desain konseptual adalah sketsa konsep dan model. (https://en.m.wikipedia.org/wiki/ Conceptual_design).

Sebagai tahapan awal dalam sebuah proses desain, desain konsepsual bertujuan untuk memberikan informasi atau gambaran awal tentang bentuk desain yang diwujudkan. Karya konsepsual harus bisa menampilkan secara visual karakteristik konsep dalam desain, sehingga masyarakat umum yang melihat dapat memahami dan merasakan suasana ruang yang ingin dicapai. Selain itu konsepsual desain dapat dikatakan sebagai fase awal di mana garis besar fungsi dan bentuk sesuatu diartikulasikan. Bentuk karya konsepsual dapat berupa desain dwimatra maupun trimatra harus bisa menampilkan secara visual karakteristik konsep dalam desainnya. Produk karya desainnya dapat berupa gambar denah, tampak/potongan, perspektif, sketsa dan bentuk modeling. Melalui desain konsepsual diharapkan kebutuhan terhadap pemanfaatan desain interior dalam pemecahan masalah yang berkaitan dengan aktifitas kehidupan manusia dapat lebih dipahami dengan baik. Dengan demikian diharapkan dengan adanya desain konseptual dapat digunakan sebagai landasan pekerjaan desain selanjutnya dalam bentuk karya Desain Pengembangan. Dalam menyusun sebuah konsep, desainer harus menyoroti unsurunsur yang membentuk desain serta membangun penalaran untuk memilih setiap elemen desain. Dengan demikian desain yang dirancang akan memiliki makna dibalik rancangannya (Wicaksono dan Tisnawati 2014).

Melalui tulisan ini dijelaskan lebih lanjut, esensi pragmatis sebuah karya konsepsual yang bertujuan untuk dapat memberikan informasi yang praktis dan jelas melalui bentuk gambar desain yang mudah dipahami, (Kamus Besar Bahasa Indonesia, https:// kbbi.web.id/pragmatis.html). Menurut (Santosa 2005) keberhasilan dari sebuah konsep perancangan tergantung pada pendekatan yang dilakukan dalam proses penyusunannya. Penggalian dan kelengkapan data pada sebuah pekerjaan desain sangat penting dan dapat lebih mempermudah dalam melakukan proses pengerjaan desain yang benar. Pendekatan desain dapat dibangun dengan beberapa langkah, yaitu pertama melalui komponen pemahaman 
desain, kedua skema perancangan analitis, ketiga pemetaan pola pikir desain, keempat metode pendekatan desain, dan kelima perumusan konsep desain. Presentasi desain konsepsual menjadi hal yang sangat penting untuk dilaksanakan dalam menentukan desain pengembangan. Seluruh masukan dari berbagai pihak menjadi bahan desain berikutnya sebagai dokumen gambar kerja. Pengembangan desain dalam bentuk gambar dokumen kerja dibuat untuk keperluan pekerjaan proyek desain interior di lapangan. Dengan demikian diharapkan karya desain konseptual yang dihasilkan dapat memberikan kontribusi bermanfaat untuk dapat dipergunakan sebagai landasan mematangkan desain selanjutnya pada "Desain Pengembangan" untuk keperluan dokumen proyek.

\section{MATERI DAN METODE}

Materi bahasan pada artikel ini berkaitan dengan beberapa hal utama yaitu: (1) Penggunaan istilah Desain Konsepsual (2) Bentuk karya Desain Konsepsual (3) Esensi karya Konsepsual pada Proyek Desain Interior. Penelitian ini dilakukan melalui proses Pengkajian Kepustakaan, Observasi langsung pada pekerjaan desain Interior disertai dengan aktifitas Dokumentasi terhadap karya desain konsepsual yang telah ada. Data dan hasil dokumentasi direduksi agar diperoleh informasi yang paling layak untuk disajikan dan dikatagorikan sesuai dengan pokok bahasan untuk dianalisis berdasarkan teori desain yg sudah dikumpulkan melalui studi kepustakaan

\section{PEMBAHASAN}

Sesuai dengan uraian yang sudah ditulis pada bagian materi pembahasan, maka tiga hal utama yang perlu dibahas tersebut dijabarkan sebagai berikut:

\section{Penggunaan istilah Desain Konsepsual.}

Desain Interior pada prinsipnya dibuat untuk memenuhi kebutuhan aktifitas manusia dalam kegiatannya didalam ruang bangunan. Desain interior dibuat bukan semata hanya untuk memperoleh wadah aktiftas manusia didalam ruangan saja, unsur estetika menjadi bagian yang disertakan didalam menentukan setiap elemen desain yang dikerjakan, sehingga aspek kepuasan fisik maupun spiritual penggunanya dapat terpenuhi. Desain Interior dikerjakan melalui beberapa tahapan pekerjaan, pertama pengumpulan data dilanjutkan dengan analisis data dengan ditunjang teori dari kepustakaan untuk mendukung penentuan pemasalahan yang ada, terakhir dirumuskan pemecahannya melalui gagasan desain yang diinginkan sesuai kosep yang ditentukan. Potensi tentang kondisi lingkungan menjadi bagian dari unsur yang dimanfaatkan pada desain interior, seperti kondisi pergerakan udara, matahari, pemandangan elevasi permukaan tanah dan sebagainya. Hal tersebut juga disebutkan, pada dasarnya rancangan desain interior selalu menitik beratkan pada unsur-unsur manusia, ruang dan lingkungan. Ketiga unsur tersebut saling terkait dan saling mempengaruhi satu sama lain dalam membentuk suasana yang diinginkan dalam sebuah perancangan interior (Suptandar 1999).

Kata desain konsepsual mungkin saja belum banyak diketahui kaitannya dengan kata "konsepsual" pada judul di atas. Oleh karena itulah, pembahasan ini perlu dilakukan agar dapat diperoleh pemahaman yang lebih mendasar. Sebuah karya desain yang benar selalu dimulai dengan penentuan "konsep" dan menghasilkan karya sesuai dengan konsep desain yang diinginkan. Wikipedia dalam terjemahan bebasnya menyebutkan, desain konseptual adalah fase awal dari proses desain, di mana garis besar fungsi dan bentuk sesuatu diartikulasikan. Ini mencakup desain interaksi, pengalaman, proses, dan strategi. Ini melibatkan pemahaman tentang kebutuhan masyarakat dan bagaimana memenuhi mereka dengan produk, layanan, dan proses. Artefak umum dari desain konseptual adalah sketsa konsep dan model. (https://en.m.wikipedia.org/wiki/ Conceptual design). Karya konsepsual harus bisa menampilkan secara visual karakteristik konsep dalam hasil desainnya, sehingga masyarakat umum dapat memahami dan merasakan suasana ruang yang ingin dicapai. Dalam penciptaan sebuah konsep desain interior diperlukan sebuah tindakan eksplorasi intelektual yang berguna untuk menangkap segala hal yang dibutuhkan dengan panca indra secara objektif. Proses penyusunan konsep haruslah menyoroti unsur-unsur yang membentuk desain tersebut serta mampu membangun penalaran untuk memilih setiap elemen desain yang digunakan. Dengan demikian, desain yang dibuat akan memiliki makna dibalik rancangannya (Wicaksono \& Tisnawati, 2014).

\section{Bentuk Karya Desain Konsepsual}

Karya Desain Konsepsual ditinjau dari bentuknya dapat bedakan dua katagori, yaitu karya dalam bentuk dwimatra dan trimatra. Karya konsepsual 
dwimatra menjadi inspirasi karya konsepsual trimatra dan begitu pula sebaliknya, dengan demikian kedua bentuk desain tersebut dapat mengarahkan untuk dapat memenuhi keinginan pemesannya. Keberhasilan karya desain konsepsual sangat tergantung pada perwujudan pada bentuk karya desain yang dilandasi ide dan gagasan yang kreatif dan estetis untuk mendapatkan daya tarik dan perhatian penggunanya. Desain konsepsual merupakan analog dengan media dwimatra maupun trimatra yang mudah dipahami, secara keseluruhan diciptakan bersama-sama untuk memberikan gambaran konsep desain yang lebih jelas. Adapun penjelasan dari karya konsepsual dwimatra dan trimatra yaitu sebagai berikut:

\section{Karya Konsepsual Dwimatra}

Desain konsepsual dwimatra adalah sebuah karya dua dimensi yang hanya bisa dinikmati dari satu arah yaitu arah depan saja dan hanya memiliki ukuran panjang dan lebar, contohkarya konsepsual dwimatra ini seperti; gambar denah, tampak / potongan, perspektif, sketsa, image foto dan lainnya. Desain konsepsual pada karya dwimatra dapat ditampilkan dengan penyelesaian dengan teknik pewarnaan yang dapat memberikan kesan realistis sesuai dengan bentuk desain dan konsep yang diinginkan.

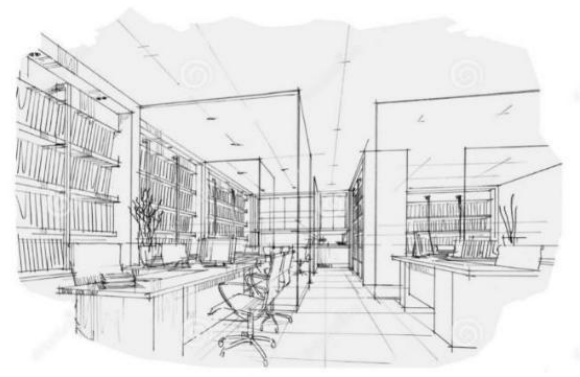

Gambar 1. Sketsa manual Perspektif Konsepsual Desain Dwimatra (Sumber: Dreamstime.com. Sketching Interior Design Stock Images and Stock Footages)

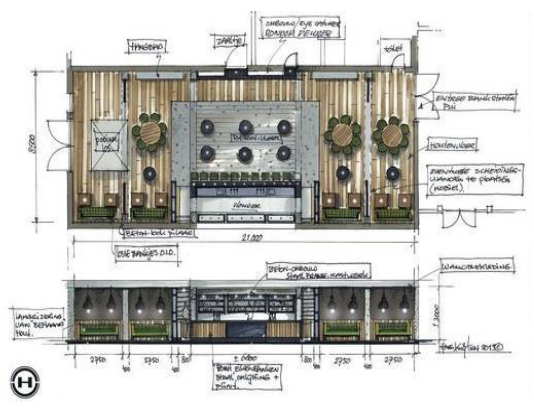

Gambar 2 Denah Penataan \& Potongan / Tampak Konsepsual Desain Dwimatra. (Sumber: Hans Kuijten Restaurant Design Restaurant Architectuur.)
Karya Desain Konsepsual diawali dengan bentuk gambar Denah Penataan Fasilitas, gambar ini menjelaskan tentang bentuk dan besaran ruang disertai tata letak fasilitasnya. Gambar Tampak dan Potongan merupakan produk desain selanjutannya yang dapat memberikan informasi tentang ketinggian dan elevasi terhadap ruang maupun fasilitas didalamnya. Gambar tersebut diambil dari gambar Denah dengan menambahkan tanda informasi bagian potongan. Gambar umumnya dibuat beberapa buah dengan sudut berbeda. Hal ini dilakukan agar dapat memberikan informasi yang selenkap mungkin tentang bagian ruang dan fasilitas yang ingin diinformasikan sesuai dengan keinginan untuk memperlihatkan bentuk desain yang ingin ditonjolkan. Pemberian informasi melalui keterangan tertulis pada setiap bagian pada gambar denah maupun tampak/potongan adalah sangat penting agar dapat membantu memperjelas informasi tentang gambar yang ditampilkan.

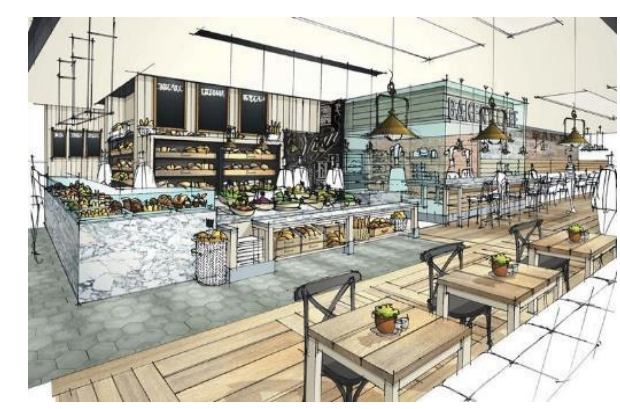

Gambar 3. Perspektif warna Konsepsual Desain Dwimatra.

(Sumber:https://trendecors.com/2020/04/22/resta urant-exterior-design-drawing/)

Karya konsepsual dwimatra lainnya selain gambar denah dan potongan adalah gambar Perspektif. Gambar Perspektif merupakan teknik menggambar objek yang dapat memberikan kesan wujud tiga dimensi dengan bantuan tarikan garis pada batas bentuk benda yang mengacu pada titik lenyap. Dibandingkan gambar denah dan potongan, gambar perspektif dapat memberikan gambaran yang lebih jelas dan mudah untuk memahami bentuk dan suasana sebuah ruangan pada sebuah gambar. 


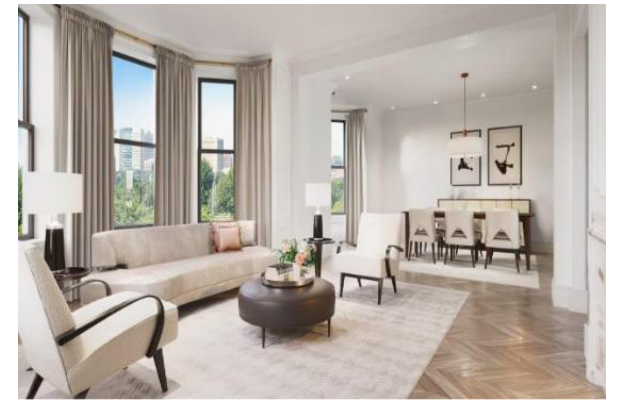

Gambar 4. Image Konsepsual Desain Dwimatra

(Sumber:https://notrianglestudio.com/servicesinterior-design-rendering)

Teknik pengerjaan gambar-gambar tersebut diatas dapat menggunakan teknik gambar manual maupun dengan teknik digital. Teknik pekerjaan dilakukan melalui ketrampilan menggunakan tangan secara langsung maupun dengan alat computer. Penggunaan teknik manual maupun digital keduanya memiliki kekurangan maupun kelebihan, hal tersebut tergantung dari kemampuan dan kemahiran yang mengerjakannya. Pengerjaan gambar desain secara manual dibutuhkan kemampuan keterampilan tangan yang mengerjakannya, sehingga dapat menghasilkan tarikan garis yang tegas. Kelebihan dari gambar manual yaitu dapat menunjukkan kekuatan dan ketrampilan tangan pada tarikan garis dari yang mengerjakannya, dan dapat dilakukan dengan lebih cepat dan praktis. Namun kekurangannya adalah keahlian menggambar manual tidak dapat dikuasai oleh semua orang, karena keahlian tersebut tidak dapat dikuasai dalam waktu yang singkat, hal lainnya penggambaran secara manual kurang realistis apabila menggambar bentuk tiga dimensi.

Salah satu keunggulan dari gambar digital adalah tampilannya yang dapat menunjukkan suasana lebih nampak realistis dari pada gambar manual. Penggambaran bentuk dan jenis material dalam gambar digital dapat menggunakan tampilan bentuk dan material dari bentuk seperti aslinya. Selain itu apabila ada perubahan dalam desain, dapat lebih mudah dirubah tanpa harus menggambarnya dari awal lagi. Pada era pos industri kekinian masyarakat awam lebih mengapresiasi kemampuan gambar tangan, selain memiliki nilai estetis dan karakter yang lebih personal dibandingkan digital yang mesin, juga gambar dengan tangan memiliki keunggulan kecepatan dibandingkan dengan digital (Noorwatha 2019). Namun dalam sebuah karya konsepsual desain interior, penggunaan keahlian gambar manual dan gambar digital dapat dipadukan sehingga dapat memperoleh hasil yang lebih maksimal

\section{Karya Konsepsual Trimatra}

Karya konsepsual trimatra adalah karya desain tiga dimensi yang bisa diamati dari segala arah dan memiliki volume. Bentuk perwujudan karya konsepsual trimarta dalam desain interior dapat berupa desain moodboard, maket maupun moke up.

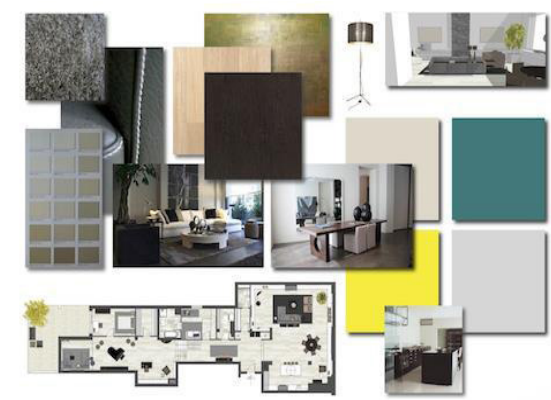

Gambar 5. Moodboard Desain Interior Dwimatra.

(Sumber: falaarquitetura.com; interiorstylehunter.com, 2019)

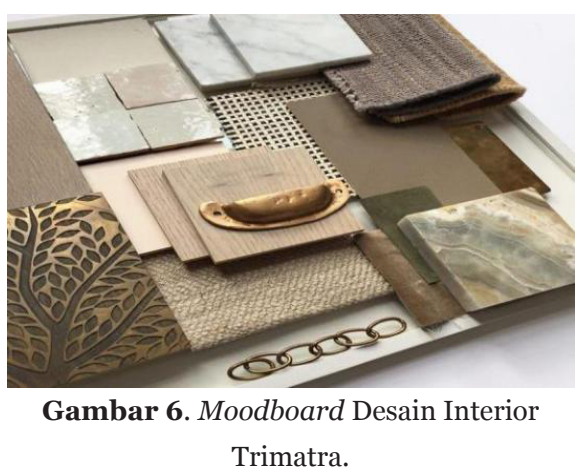

(Sumber: falaarquitetura.com; interiorstylehunter.com, 2019)

Moodboard atau ada juga yang menyebutkan sebagai "papan konsep" merupakan sebuah bentuk produk yang berfungsi sebagai materi presentasi bertujuan untuk dapat memberikan gambaran secara riil bentuk pilihan unsur desain yang dapat dilihat secara nyata. Bentuk tersebut dapat berupa penetuan penggunaan warna, material, alat-alat maupun lainnya yang berhubungan dengan desain yang dikerjakan.. Moodboard dibuat pada sebuah papan yang materinya merupakan gabungan dari citra gambar, wujud potongan material sebenarnya yang akan digunakan dalam desain, dan elemenelemen estetis lainnya (Noorwatha 2019). Adapun tujuan dibuatnya moodboard dalam tahapan konsepsual desain interior, yaitu untuk memberikan informasi yang lebih jelas mengenai desain yang diwujudkan. Sebagai kelengkapan dalam karya 
konsepsualnya diperlukan moodboard yang dapat menjelaskan produk desainnya, secara lebih mendalam tentang detil material maupun seluruh produk yang digunakannya. Informasi seluruh detil tersebut dapat ditampilkan pada desain moodboard yang dibuatnya, seluruh material dan produk dapat secara nyata dilihat dan dipilih oleh pemesannya. Keserasian pemilihan material maupun produk mendapatkan perhatian sehingga menghasilkan perpaduan bentuk maupun warna yang maksimal. Melalui moodboard lebih mudah untuk melihat kecocokan antara tampilan warna, texture, motif dan bentuk dari material asli yang digunakan, sehingga dapat terhindar dari kesalahan dalam memilih material yang digunakan.

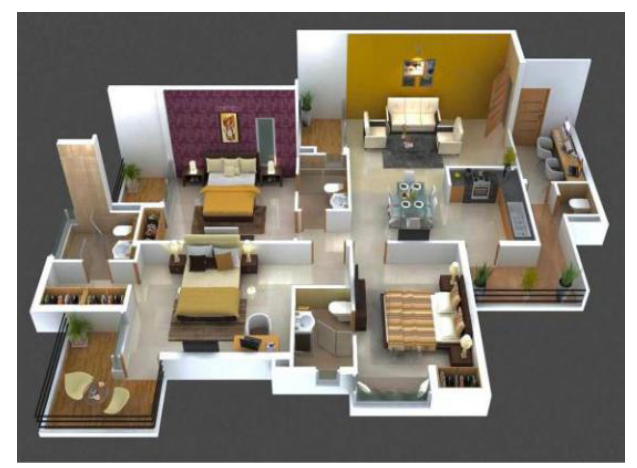

Gambar 7. Desain Interior Trimatra berbentuk maket.

(Sumber: Face Book. 3D Floor Plans-

Collections \# 3d\#plans\#kientrucdep\#nhadep\#noithatd ep)

Selain moodboard, karya konsepsual trimatra lainnya adalah Desain Maket. Karya desain maket merupakan perwujudan desain ke dalam sebuah miniatur yang dibuat dengan skala tertentu. Pembuatan desain maket bertujuan untuk memberikan gambaran desain yang lebih jelas dalam bentuk tiga dimensi. Bentuk maket diwujudkan berupa keseluruhan ruang yang ada pada bangunan atau mengambil salah satu ruang yang ingin ditonjolkan. Karya desain maket bertujuan untuk dapat memperlihatkan bentuk seluruh elemen ruang dengan seluruh fasitas yang ada didalamnya. Desain maket dikerjakan dengan menggunakan material yang menyerupai karakter desainnya. Penampilan maket juga sering disertakan dengan penempatan penyinaran sesuai dengan desain pencahayaan yang diinginkan, sehingga efek cahaya ditampilkan dapat memberikan nuansa estetis sesuai dengan konsepnya.

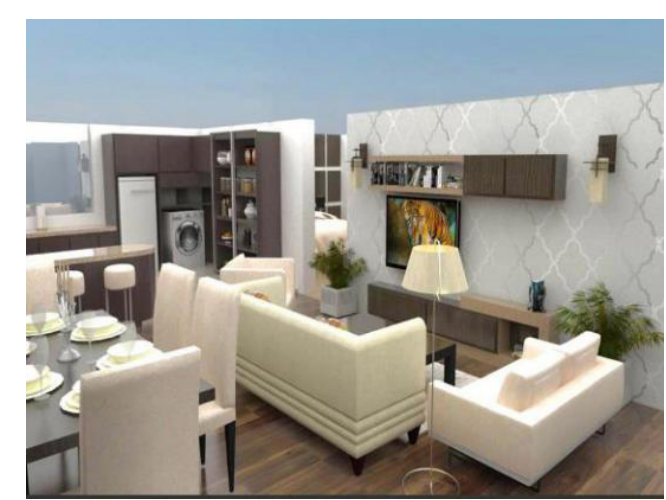

Gambar 8. Desain Interior Trimatra berbentuk Moke up (Sumber: Face Book. 3D Floor Plans-

Collections

\#3d\#plans\#kientrucdep\#nhadep\#noithatd

ep)

Bentuk desain konsepsual trimatra lainnya adalah moke-up, sebagai contoh perwujudan desain yang biasa digunakan dalam sebuah proyek interior maupun pameran produk desain interior. Bila maket dibuat sebagai miniatur dalam bentuk skala tertentu, maka moke-up adalah sebuah produk perwujudan desain interior yang dibuat dengan skala $1: 1$ yang dibuat dengan material dan ukuran sebenarnya. Moke-up dibuat bertujuan untuk dapat menampikan bentuk dan suasana yang nyata dari sebuah ruang beserta fasilitasnya pada desain interior. Dari adanya moke-up tersebut dapat dilihat maupun dirasakan oleh pemesan secara langsung, kalau ada bagian yang kurang sesuai dengan keinginannya agar dapat dikembangkan menjadi lebih baik guna memaksimalkan desain yang diinginkan.

\section{Esensi Karya Konsepsual pada Proyek Desain Interior.}

Pembahasan tentang esensi karya konsepsual dalam hubungannya dengan pelaksanaan proyek dilapangan adalah sangat penting untuk diuraikan, agar nantinya dapat diketahui secara jelas Esensi dari Karya Konsepsual dalam sebuah pekerjaan Proyek Desain Interior.

\section{Desain Konsepsual sebagai Materi Pemahaman karya Desain Awal.}

Produk karya awal desain interior disebut sebagai karya konsepsual, karya ini harus dapat memberikan informasi yang jelas tentang nilai fungsi dan keindahan yang terkandung didalam setiap keinginan 
pemesannya sesuai konsep yang ditentukan. Karya Karya tersebut dibuat beryujuan untuk mendapatkan gambaran secara menyeluruh desain interior yang dikerjakan. Bentuk-bentuk karya desain konseptual sudah diuraikan dengan jelas tersebut diatas, yaitu dalam bentuk desain dwimatra maupun trimatra, bentuk desain yang dikerjakan tersebut disesuaikan dengan kebutuhan dari pemesannya. Bentuk desain dibuat agar mudah dipahami pemesan, dengan demikian seluruh bentuk desain dibuat agar realistis menyerupai bentuk yang sebenarnya. Setiap unsur desain interior dikerjakan dengan menampilkan bentuk, dimensi maupun penyelesaian warna yang menarik, sehingga kesan konsep yang tertuang didalamnya dapat dirasakan. Untuk mengontrol jalannya pekerjaan desain agar tidak terlalu jauh menyimpang dari keinginan pemesannya, perlu diadakan evaluasi pekerjaan yang sudah diselesaikan sebelum menginjak pekerjaan selanjutnya berupa presentasi desain.

\section{Desain Konsepsual sebagai Bahan Evaluasi Presentasi Desain}

Evaluasi desain sangat diperlukan dalam menentukan hasil desain konsepsual yang telah diselesaikan, apakah desain tersebut dapat diselesaikan sesuai dengan keinginan pemesannya atau tidak. Dengan demikian setelah keseluruhan karya desain konsepsual diselesaikan, dilanjutkan dengan mengadakan evaluasi terhadap seluruh bentuk desain melalui pertemuan dalam forum presentasi desain. Dalam presentasi tersebut dijelaskan metode yang digunakan, berikutnya diuraikan seluruh proses desain yang dikerjakan sampai pada menginformasikan bentuk karya desain konsepsual yang dihasilkan, sehingga seluruh penjelasan dapat dipertanggung jawabkan dihadapan seluruh peserta forum dengan baik. Hal yang terpenting dalam presentasi tersebut adalah, peserta yang hadir khususnya pemesan dapat dengan jelas mengetahui dan memahami materi dan hasil desain yang diungkapkan dalam presentasi tersebut, dengan tujuan keseluruhan kritikan dan masukan yang didapatkan dari kegiatan forum presentasi dapat diterima desainer untuk menjadi bagian masukan pada pekerjaan pengembangan desain berikutnya.

\section{Desain Konsepsual sebagai Sumber Materi Desain Pengembangan.}

Bila karya konseptual adalah ditekankan pada penjabaran konsep dalam bentuk karya desain yang mudah dipahami semua orang, maka "Desain
Pengembangan" merupakan karya lanjutan yang dibuat dari hasil evaluasi dan masukan presentasi desain konseptual. Karya Desain Pengembangan dilanjutkan dengan Desain Detil merupakan karya yang bersifat teknis, karena gambar ini digunakan untuk berkomunikasi dengan kontraktor sebagai pelaksana perwujudan di lapangan. Karya Desain Pengembangan dan Detail lebih menekankan pada kejelasan bentuk, ukuran, material dan konstruksi yang digunakan beserta penjelasannya melalui pemberian keterangan penting lainnya yang bersifat teknis sebagai pedoman kerja dalam mewujudkan sebuah desain. Seluruh gambar Desain Pengembangan dan Detil dirangkum menjadi satu untuk dapat digunakan sebagai dokumen pedoman kerja oleh pelaksana dilapangan. Dalam tahap perwujudan desain, seorang Desainer Interior selalu bekerjasama dengan pihak lain seperti Arsitek, Sipil, Kontraktor dan pihak-pihak lainnya, sehingga kerja sama tersebut diharapkan menghasilkan perwujudan desain yang memuaskan sesuai dengan keinginan pemesannya. Dengan demikian kelengkapan dan kejelasan gambar, kerjasama dan komunikasi yang baik sangat diperlukan dalam pelaksanaan pekerjaan pada proyek desain interior.

\section{SIMPULAN}

Berdasarkan penjelasan tersebut diatas, maka dapat disusun simpulan esensi desain konsepsual dalam proyek desain interior adalah sebagai berikut:

Desain Konsepsual adalah produk desain tahapan yang pertama dikerjakan, bertujuan memberikan informasi sebagai gambaran awal tentang bentuk keseluruhan desain yang yang diinginkan. Desain harus bisa menampilkan secara visual karakteristik konsep pada setiap bentuk desain, sehingga khalayak umum yang melihat dapat memahami dan dapat merasakan suasana ruang sesuai konsep yang digunakan.

Bentuk karya Desain Konsepsual dapat dikerjakan dalam karya dwimatra maupun trimatra, bertujuan untuk dapat memberikan informasi yang praktis dan jelas melalui bentuk yang mudah dipahami. Keberhasilan karya desain konsepsual sangat tergantung pada penampilan bentuk desain yang melandasi pemikiran kreatif dengan ditunjang oleh unsur estetika bertujuan mendapatkan daya tarik dan perhatian penggunanya. 
Presentasi Desain oleh Desainernya sangat diperlukan sebagai bagian evaluasi dan control hasil pekerjaan desain konsepsual. Presentasi desain dilakukan pada akhir pekerjaan desain. Hal ini penting dilaksanakan untuk dapat mengetahui keberhasilan desainer dalam memenuhi keinginan pemesan sesuai dengan konsep yang ditentukan. Dengan demikian kekurangan, kesalahan dan masukan yang ditemukan menjadi bagian penting untuk dipergunakan dalam mengerjakan desain selanjutnya pada Desain Pengembangan.

\section{DAFTAR RUJUKAN}

Conceptual design. (2021). Dalam Wikipedia. https://en.wikipedia.org $/ \mathrm{w} /$ index.php?title $=\mathrm{C}$ onceptual design\&oldid $=999266545 \quad$ (Diakses tanggal 29 Mei 2021)

Ching, Francis D. K. 2002. Arsitektur: Bentuk, Ruang dan Tatanan. Jakarta: Erlangga.

Ching, Francis D. K., dan Corky Binggeli. 2011. Desain InteriorDenganIlustrasi. Jakarta: Indeks.

Ching, Francis. D. K. (2011), Interior Design Illustrated Second Edition, terjemahan Lois Nur Fathia Praja (2011), PT Indeks, Jakarta.

Dreamstime.com. Sketching Interior Design Stock Images and Stock Footages (diakses tanggal 29 Mei 2021).

Dazzling Hacks Industrial Chair Wood Industrial Loft Garage. https://trendecors.com/2020/04/22/ restaurant-exterior-design-drawing/ (diaksestanggal 29 Mei 2021).

FaceBook. 3D Floor Plans-Collections \#3d\#plans \#kientrucdep \# nhadep \# noithatdep. updated 25 May 2017 (Diakses pada tanggal 29 Mei 2021)

Hans Kuijten Restaurant Design Restaurant Architectuur.

https://trendecors.com/2020/04/22/restaura ntexterior-design-drawing/ (Diakses pada tanggal 29 Mei 2021)

Lawson, B. 2001. The Language of Space. Oxford: Architectural Press.
Living Room Rendering of a Townhouse Unit in Austin, Texas. https://notrianglestudio.com/ services-interior-design-rendering (Diakses pada tanggal 29 Mei 2021)

Moodboards. : fala arquitetura.com; interior style hunter.com, 2019 (Diakses pada tanggal 29 Mei 2021).

Noorwatha, I. Kadek Dwi. 2019. Pancaksana: Tahapan Desain Interior Berbasis Budaya Berwawasan Universal. Denpasar: Cakra Media Utama.

Rucitra, A. A. (2020). Merumuskan Konsep Desain Interior. Jurnal Desain Interior, 5(1), 31. https:// doi.org/10.12962/j12345678.v5i1.7020

Santosa, Adi. 2005. "Pendekatan Konseptual Dalam Proses Perancangan Interior." Dimensi Interior 3(2). 111-123. doi:10.9744/interior.3.2.

Sastroasmoro, S., Ismail, S. (2002). Dasar-Dasar Metodologi Penelitian Klinis.Edisi ke-2.Jakarta: Sagung Seto.

Suptandar, J. Pamudji. 1995. Manusia dan Ruang dalam Proyeksi Desain Interior. Jakarta: UPT Penerbitan Universitas Tarumanegara.

Suptandar, J. Pamudji. 1999. Disain Interior : Pengantar Merancang Interior Untuk Mahasiswa Desain dan Arsitektur. Jakarta: Djambatan.

Wicaksono, Andie A., dan Endah Tisnawati. 2014. Teori Interior. Jakarta: Griya Kreasi. 